\title{
Facile Preparation and Highly Efficient Sorption of Magnetic Composite Graphene Oxide/Fe304/GC for Uranium Removal
}

\author{
Aili Yang ( $\sim$ yang770117@sina.com ) \\ China Academy of Engineering Physics
}

\section{Zhijun Wang}

China Academy of Engineering Physics

\section{Yukuan Zhu}

China Academy of Engineering Physics

\section{Research Article}

Keywords: Graphene oxide, magnetic, thermodynamic

Posted Date: January 29th, 2021

DOI: https://doi.org/10.21203/rs.3.rs-150676/v1

License: (1) This work is licensed under a Creative Commons Attribution 4.0 International License.

Read Full License

Version of Record: A version of this preprint was published at Scientific Reports on April 19th, 2021. See the published version at https://doi.org/10.1038/s41598-021-86768-0. 


\title{
Facile preparation and highly efficient sorption of magnetic composite graphene oxide/ $\mathrm{Fe}_{3} \mathrm{O}_{4} / \mathrm{GC}$ for uranium removal
}

\author{
Aili Yang ${ }^{1}$, Zhijun Wang ${ }^{1} \&$ Yukuan Zhu ${ }^{1}$
}

In this work, we reported for the first time a novel magnetic composite graphene oxide/ $\mathrm{Fe}_{3} \mathrm{O}_{4} /$ glucose- $\mathrm{COOH}\left(\mathrm{GO} / \mathrm{Fe}_{3} \mathrm{O}_{4} / \mathrm{GC}\right)$ that was facilely prepared from glucose through the hydrothermal carbonization and further combination with graphene oxide (GO). The chemical and structural properties of the samples were investigated. By the batch uranium adsorption experiments, the magnetic composite $\mathrm{GO} / \mathrm{Fe}_{3} \mathrm{O}_{4} / \mathrm{GC}$ exhibits an excellent adsorption performance and fast solid-liquid separation for uranium from aqueous solution. $\mathrm{GO} / \mathrm{Fe}_{3} \mathrm{O}_{4} / \mathrm{GC}$ (the maximum adsorption capacity $\left(Q_{\mathrm{m}}\right)$ was $390.70 \mathrm{mg} \mathrm{g}^{-1}$ ) exhibited excellent adsorption capacity and higher removal rate (> 99\%) for U(VI) than those of glucose-COOH (GC) and magnetic GC (MGC). The effect of the coexisting ions, such as $\mathrm{Na}^{+}$, $\mathrm{K}^{+}, \mathrm{Mg}^{2+}, \mathrm{Ca}^{2+}$, and $\mathrm{Al}^{3+}$, on the $\mathrm{U}(\mathrm{VI})$ removal efficiency of $\mathrm{GO} / \mathrm{Fe}_{3} \mathrm{O}_{4} / \mathrm{GC}$ was examined. The equilibrium sorption and sorption rate for the as-prepared adsorbents well fit the Langmuir model and pseudo second-order kinetic model, respectively. The thermodynamic parameters $\left(\Delta H^{0}=11.57 \mathrm{~kJ} \mathrm{~mol}^{-1}\right.$ and $\Delta G^{0}$ $<0)$ for $\mathrm{GO} / \mathrm{Fe}_{3} \mathrm{O}_{4} / \mathrm{GC}$ indicate that the sorption process of $\mathrm{U}(\mathrm{VI})$ was exothermic and spontaneous. Thus, this research provides a facile strategy for the preparation of the magnetic composite with low cost, high efficiency and fast separation for the $\mathrm{U}(\mathrm{VI})$ removal from aqueous solution.

Nowadays, carbonaceous materials, such as activated carbon ${ }^{1}$, carbon nanotubes ${ }^{2}$, carbon fibre ${ }^{3}$, and mesoporous carbon ${ }^{4}$, have been widely applied due to their availability, acid-base stability, and thermal resistance. These carbonaceous materials generally are fabricated via high temperature reaction ${ }^{5}$, pyrolysis $^{6-8}$, gasfication ${ }^{9}$, electrospinning technique ${ }^{10}$, etc. Amongst these techniques, hydrothermal carbonization (HTC) has become a proficient synthesis technique owing to its cheapness, simplification, mild reaction conditions, and lack of any organic solvent and toxic waste. The fabrication of the biomass modification product by HTC process is one of the hot spots in recent years ${ }^{11-13}$. As a branch of carbonaceous materials the HTC materials from biomass have emerged since $1913^{14}$, and exhibited significant potential in various fields, such as adsorption ${ }^{15-18}$, catalysis ${ }^{19}$, fuel cell ${ }^{20}$, and energy storage/conversion ${ }^{21-23}$. Among the potential precursors for the preparation of HTC materials, glucose as a promising candidate has drawn much attention ${ }^{24}$. Glucose with low-cost and non-toxicity is a natural organic biomass, and reacts with heavy metals and influence their migration behaviour.

With increasing development of all kinds of industry, severe water pollution caused by reckless discharge into water has critically threatened human health and ecosystem ${ }^{25}$. Adsorption is a popular technique to resolve water contamination problems due to its low energy consumption, easiness, effectiveness, and no secondary pollution ${ }^{26,27}$. The glucose-based adsorbents have been proved to be promising for the removal of various pollutants, such as antibiotics ${ }^{28}$, organic pollutants $^{29}$, gas pollutants ${ }^{30}$, dyes ${ }^{31}$, and heavy metal ions ${ }^{32,33}$. However, glucose treated solely by a hydrothermal approach possesses poor pore configuration, undeveloped porosity and low adsorption capacity, which make it being rarely applied in the removal of the pollutants ${ }^{12}$. Therefore, it is significant to develop novel glucose derivatives with numerous functional group in order to enhance the property.

Graphene oxide (GO) has been proved a popular candidate as a template for fabricating other functional nanomaterials, owing to its unique layered structure and remarkable physicochemical properties, such as high surface area, hydrophobicity, conductivity, and elasticity. Moreover, GO as an adsorbent can efficiently capture contaminants in water for water remediation ${ }^{34}$. However, the excellent dispersion of GO increases difficulty in separation between GO and treated solution, and tend to agglomerate after adsorption which lessens the adsorption capacity of $\mathrm{GO}^{35}$. To overcome these drawbacks of $\mathrm{GO}$, the functionalization of GO with other materials, such as glucose, has become a promising tendency ${ }^{36}$. The addition of inexpensive glucose onto GO can effectively reduce the production cost of the adsorbent, and obtain abundant active

${ }^{1}$ Aili Yang: Institute of Materials, China Academy of Engineering Physics, P.O. Box 9071-7, Mianyang, 621907, China.

${ }^{1}$ Zhijun Wang: Institute of Materials, China Academy of Engineering Physics, P.O. Box 9071-7, Mianyang, 621907, China.

${ }^{1}$ Yukuan Zhu: Institute of Materials, China Academy of Engineering Physics, P.O. Box 9071-7, Mianyang, 621907, China.

Correspondence and requests for materials should be addressed to Aili Yang. (Email: yang770117@sina.com, Tel/Fax: 086-18380598619/086-0816-3625900). 
oxygen group simultaneously. Xie et al synthesized glucose-based carbon nanosheets by an integrated GO-confined nanospace directed $\mathrm{KOH}$-activated process for the removal of sulfamethazine ${ }^{37}$. Martín-Jimeno et al prepared HTC xerogels via hydrothermal carbonization of glucose in the presence of GO as morphology directing agent and $\mathrm{KOH}$ activation method for $\mathrm{CO}_{2}$ and dye adsorption ${ }^{38}$. However, the preparation methods for these glucose-based composites have some major drawbacks, such as high energy cost, operation complexity, and soli-liquid separation difficulty.

In order to overcome the separation problem, green and inexpensive magnetic nanoparticles, such as $\mathrm{Fe}_{3} \mathrm{O}_{4}$, have drawn considerable attention due to their environmentally friendliness and unique magnetic behaviour ${ }^{39-41}$. The existence of $\mathrm{Fe}_{3} \mathrm{O}_{4}$ makes solid substance be rapidly separated from liquid phase only through an external magnetic field to shorten the wastewater treatment period. To our best knowledge, few researches focus on the preparation of the magnetic glucose-based adsorbent with GO as the template for the removal of uranium. Herein, in the present work, a magnetic GO-functionalized HTC adsorbent $\left(\mathrm{GO} / \mathrm{Fe}_{3} \mathrm{O}_{4} / \mathrm{GC}\right)$ was synthesized using glucose as the carbon precursor via hydrothermal carbonization and magnetization reaction, which aims to develop a novel high-efficiency adsorbent for the removal of U(VI) from nuclear waste influent. The fabrication process and magnetization curve of $\mathrm{GO} / \mathrm{Fe}_{3} \mathrm{O}_{4} / \mathrm{GC}$ (magnetization saturation value is 23.79 $\mathrm{emu}^{-1}$ ) are shown in Fig. 1. The samples were characterized by elements analysis, crystal phase, functional group, and thermal stability. To evaluate the removal performance of the samples for $\mathrm{U}(\mathrm{VI})$, the batch adsorption experiments were carried out, and the kinetic and thermodynamic parameters in the adsorption process were provided.

\section{Results and discussion}

Characterization. The FTIR spectra of glucose, $\mathrm{Fe}_{3} \mathrm{O}_{4}, \mathrm{GC}, \mathrm{MGC}$ and $\mathrm{GO} / \mathrm{Fe}_{3} \mathrm{O}_{4} / \mathrm{GC}$ were shown in Fig. 2A. In the IR spectrum of GC, most of the characteristic peaks disappeared compared to glucose, but the intensity of the band at 1714 $\mathrm{cm}^{-1}$ was higher than that of glucose, which indicated that GC was successfully obtained after hydrothermal and calcination treatment, and the number of carboxyl, carbonyl and ester groups significantly increased on the surface. These characteristic peaks of GC were similar to those of HTC-COOH reported in the reference [42]. In the IR spectrum of GO/Fe $\mathrm{O}_{4} / \mathrm{GC}$, the characteristic peaks at $\sim 567 \mathrm{~cm}^{-1}$ and $\sim 352 \mathrm{~cm}^{-1}$ belonged to Fe-O stretching vibration appeared, suggesting that the magnetic composite $\mathrm{GO} / \mathrm{Fe}_{3} \mathrm{O}_{4} / \mathrm{GC}$ was successfully prepared.

The XRD crystal phases of the samples were presented in Fig. 2B. In the XRD pattern of glucose, the strong diffraction peaks reflected great crystallization of glucose. However, the crystal phase of GC is amorphous owing to the calcination process in $300{ }^{\circ} \mathrm{C}$, which accords with the reference [43]. The structures of MGC and GO/Fe $3 \mathrm{O}_{4} / \mathrm{GC}$ are also amorphous due to the existence of GC. Moreover, the XRD peaks at $2 \theta$ values of the purchased $\mathrm{Fe}_{3} \mathrm{O}_{4}$ are about $29.94^{\circ}$, $35.30^{\circ}, 42.98^{\circ}, 53.38^{\circ}, 56.84^{\circ}, 62.46^{\circ}$ and $74.84^{\circ}$. The XRD patterns of $\mathrm{GO} / \mathrm{Fe}_{3} \mathrm{O}_{4} / \mathrm{GC}$ and $\mathrm{MGC}$ are basically consistent with those of $\mathrm{Fe}_{3} \mathrm{O}_{4}$, while the intensity of the peaks has significantly reduced compared to $\mathrm{Fe}_{3} \mathrm{O}_{4}$ because of the addition of GO and GC.

To reveal the thermal stability of the samples, the TGA curves of glucose, GC, MGC and GO/Fe $3 \mathrm{O}_{4} / \mathrm{GC}$ in the range of temperatures from 30 to $900{ }^{\circ} \mathrm{C}$ are shown in Fig. 2C. The composite $\mathrm{GO} / \mathrm{Fe}_{3} \mathrm{O}_{4} / \mathrm{GC}$ presented the smallest weight loss (4.28\%) when the temperature was up to $900{ }^{\circ} \mathrm{C}$, which showed that $\mathrm{GO} / \mathrm{Fe}_{3} \mathrm{O}_{4} / \mathrm{GC}$ had the excellent thermal stability and almost no thermal decomposition took place. While the thermal stability of glucose, GC and MGC was poor, and the weight losses at $900{ }^{\circ} \mathrm{C}$ were $76.79 \%, 49.67 \%$ and $16.48 \%$, respectively.

The element composition of $\mathrm{Fe}_{3} \mathrm{O}_{4}$, glucose, GC, MGC and $\mathrm{GO} / \mathrm{Fe}_{3} \mathrm{O}_{4} / \mathrm{GC}$ was investigated by XPS. The XPS survey spectrum of $\mathrm{GO} / \mathrm{Fe}_{3} \mathrm{O}_{4} / \mathrm{GC}$ (Fig. 3A) shows that the evident characteristic peaks at about 285, 554, 711 and $725 \mathrm{eV}$ attributed to $\mathrm{C} 1 \mathrm{~s}, \mathrm{O} 1 \mathrm{~s}$ and $\mathrm{Fe} 2 \mathrm{p}$, respectively. In the high-resolution spectrum of $\mathrm{Fe} 2 \mathrm{p}$ (Fig. 3B), the peaks of Fe 2p $3 / 2$ and $\mathrm{Fe} 2 \mathrm{p}_{1 / 2}$ are located at $711.30 \mathrm{eV}$ and $724.70 \mathrm{eV}$, respectively, indicating the presence of $\mathrm{Fe}_{3} \mathrm{O}_{4}$ in the composite $\mathrm{GO} / \mathrm{Fe}_{3} \mathrm{O}_{4} / \mathrm{GC}$.

Based on the above characterization results, a possible formation mechanism for $\mathrm{GO} / \mathrm{Fe}_{3} \mathrm{O}_{4} / \mathrm{GC}$ is illustrated in Fig. 4. Firstly, GO nanosheet is physically mixed with GC in an ultrasonic bath to form the complex GO • GC through hydrogen bond interaction as shown in Eq. (1). Then, $\mathrm{Fe}^{\mathrm{n}+}(\mathrm{n}=2,3)$ ions were formed in the above suspension by adding $\mathrm{Fe}^{2+}$ ions because a part of $\mathrm{Fe}^{2+}$ ions were oxidized to $\mathrm{Fe}^{3+}$ in air by the redox reaction as shown in Eq. (2). With the hydrolysis of $\mathrm{Fe}^{3+}$ and the addition of $30 \%$ ammonia solution the magnetic composite $\mathrm{GO} / \mathrm{Fe}_{3} \mathrm{O}_{4} / \mathrm{GC}$ was obtained as expressed in Eqs. (3) and Eq. (4). Thus, both $\mathrm{GC}$ and $\mathrm{Fe}_{3} \mathrm{O}_{4}$ are immobilized on the surface of GO. 
$\mathrm{GO}+\mathrm{GC} \longrightarrow \mathrm{GO} \cdot \mathrm{GC}$

$\mathrm{Fe}^{2+} \underset{\mathrm{O}_{2} \text { in air }}{\stackrel{\text { redox reaction }}{\longrightarrow}} \mathrm{Fe}^{3+} \longrightarrow \mathrm{Fe}^{\mathrm{n}+}(\mathrm{n}=2,3)$

$\mathrm{Fe}^{3+}+\mathrm{H}_{2} \mathrm{O} \stackrel{\text { hydrolysis }}{\longrightarrow} \mathrm{Fe}(\mathrm{OOH})$

$\mathrm{GO} \cdot \mathrm{GC}^{*} \mathrm{Fe}^{\mathrm{n}+}(\mathrm{n}=2,3)+\mathrm{Fe}(\mathrm{OOH}) \stackrel{30 \% \mathrm{NH}_{3} \cdot \mathrm{H}_{2} \mathrm{O}}{\mathrm{pH}=11} \mathrm{GO} / \mathrm{Fe}_{3} \mathrm{O}_{4} / \mathrm{GC}$

Adsorption tests. The effect of the solution $\mathrm{pH}$ on the adsorption efficiency of the as-prepared adsorbents toward U(VI) is exhibited in Fig. 5A. The results show that the adsorption process for U(VI) obviously depends on the $\mathrm{pH}$ value of the solution. The $\mathrm{pH}$ value of the solutions greatly affects the surface charge of the samples. At $\mathrm{pH}<4.0$, the surface of the sorbents were protonated to form the positively charged surface, and then the electrostatic repulsion between these positive charge (including $\mathrm{H}_{3} \mathrm{O}^{+}$) and $\mathrm{UO}_{2}{ }^{2+}$ led to the poor adsorption capability for $\mathrm{U}(\mathrm{VI}){ }^{14} \mathrm{With}$ the appearance of the positive species $\left(\mathrm{UO}_{2}(\mathrm{OH})^{+},\left(\mathrm{UO}_{2}\right)_{3}(\mathrm{OH})_{5}{ }^{+}\right.$, and $\left.\left(\mathrm{UO}_{2}\right)_{4}(\mathrm{OH})_{7}{ }^{+}\right)$the removal efficiency of $\mathrm{U}(\mathrm{VI})$ significantly increased at $\mathrm{pH}$ 4.0-7.0 due to the electrostatic interaction between these complex uranium ions with positive charges and the negatively charged adsorbents. When $\mathrm{pH}$ is above 7.0 , the negatively charged $\mathrm{U}(\mathrm{VI})$ species $\left(\left(\mathrm{UO}_{2}\right)_{3}(\mathrm{OH})_{7}{ }^{-}\right.$and $\left.\mathrm{UO}_{2}(\mathrm{OH})_{3}{ }^{-}\right)$are the dominant $\mathrm{U}(\mathrm{VI})$ species in solution which result in the reduction of the U(VI) removal efficiency. ${ }^{44}$ The maximum removal rate for $\mathrm{GC}, \mathrm{MGC}$ and $\mathrm{GO} / \mathrm{Fe}_{3} \mathrm{O}_{4} / \mathrm{GC}$ was $66.30 \%(\mathrm{pH} \mathrm{6.0),} \mathrm{73.30 \%} \mathrm{(pH} \mathrm{5.0),} \mathrm{and} \mathrm{98.70 \%} \mathrm{(pH} \mathrm{5.0),} \mathrm{respectively.} \mathrm{The}$ sorption efficiency of $\mathrm{U}(\mathrm{VI})$ by $\mathrm{GO} / \mathrm{Fe}_{3} \mathrm{O}_{4} / \mathrm{GC}$ was much higher than that of $\mathrm{GC}$ indicating that the addition of GO in the GC molecular enhanced greatly the adsorption property for $\mathrm{U}(\mathrm{VI})$. As a consequence, the optimal $\mathrm{pH}$ for GC, MGC and $\mathrm{GO} / \mathrm{Fe}_{3} \mathrm{O}_{4} / \mathrm{GC}$ was selected as 6.0, 5.0 and 5.0 in the next $\mathrm{U}(\mathrm{VI})$ adsorption tests, respectively.

The influence of some important co-existing cations (e.g., $\mathrm{Na}^{+}, \mathrm{K}^{+}, \mathrm{Ca}^{2+}, \mathrm{Mg}^{2+}$, and $\mathrm{Al}^{3+}$ ) on U(VI) sorption by $\mathrm{GO} / \mathrm{Fe}_{3} \mathrm{O}_{4} / \mathrm{GC}$ at $298 \mathrm{~K}$ and $\mathrm{pH} 5.0$ was shown in Fig. 5B. It was clearly seen that $\mathrm{Na}^{+}, \mathrm{K}^{+}, \mathrm{Mg}^{2+}$ and $\mathrm{Ca}^{2+}$ had no significant competition effects on the sorption of $\mathrm{U}(\mathrm{VI})$. In contrast, the presence of $\mathrm{Al}^{3+}$ had a suppressive effect on U(VI) sorption. The results showed that the binding ability of cations to $U(V I)$ followed the priority sequence: +3 valence cations (e.g., $\left.\mathrm{Al}^{3+}\right)<+2$ valence cations (e.g., $\mathrm{Mg}^{2+}$ and $\mathrm{Ca}^{2+}$ ) $<+1$ valence cations (e.g., $\mathrm{Na}^{+}$and $\mathrm{K}^{+}$) which indicated that the better electrostatic interaction between high valence cations and the adsorbent $\mathrm{GO} / \mathrm{Fe}_{3} \mathrm{O}_{4} / \mathrm{GC}$ result in the decrease of the adsorption efficiency for U(VI).

Adsorption isotherm. The fit results of Langmuir, Freundlich and Dubinin-Radushkevich (D-R) isotherm models for the $\mathrm{U}(\mathrm{VI})$ adsorption on $\mathrm{GC}$ and $\mathrm{GO} / \mathrm{Fe}_{3} \mathrm{O}_{4} / \mathrm{GC}$ are presented in Fig. 6. The Langmuir, Freundlich and D-R isotherm parameters are calculated and listed in Table 1. It was clearly seen that the Langmuir equation of the adsorbents fitted well the experimental data with a higher correlation coefficient compared to Freundlich and D-R adsorption isotherm models. The maximum sorption capacity $\left(Q_{\mathrm{m}}\right)$ of $\mathrm{U}(\mathrm{VI})$ on $\mathrm{GC}$ and $\mathrm{GO} / \mathrm{Fe}_{3} \mathrm{O}_{4} / \mathrm{GC}$ was determined to be $396.85 \mathrm{mg} \mathrm{g}^{-1}$ and 390.70 $\mathrm{mg} \mathrm{g}^{-1}$, respectively, higher than those of the previously reported glucose-based materials (see Table 2), which indicated that $\mathrm{GO} / \mathrm{Fe}_{3} \mathrm{O}_{4} / \mathrm{GC}$ was a promising adsorbent for the treatment of the uranium-bearing wastewater.

According to the D-R isotherm parameters, the obtained $E$ values reveal the physical or chemical sorption mechanism. According to the literature ${ }^{45}$, if $E$ lies between 8 and $16 \mathrm{~kJ} \mathrm{~mol}^{-1}$, the sorption process takes place chemically whereas $E<8$ $\mathrm{kJ} \mathrm{mol}^{-1}$ follows the physical sorption. For $\mathrm{GC}$ and $\mathrm{GO} / \mathrm{Fe}_{3} \mathrm{O}_{4} / \mathrm{GC}$, low $E$ value $\left(<8 \mathrm{~kJ} \mathrm{~mol}^{-1}\right)$ obtained in this study suggested that the mechanism of $U$ adsorption was the physical adsorption process due to electrostatic interaction or Van der Waal's attraction.

Table 1. Parameters of Langmuir, Freundlich and D-R model for $\mathrm{U}(\mathrm{VI})$ adsorption on $\mathrm{GC}$ and $\mathrm{GO} / \mathrm{Fe}_{3} \mathrm{O}_{4} / \mathrm{GC}$.

\begin{tabular}{|c|c|c|c|c|c|c|c|c|c|c|}
\hline \multirow[b]{2}{*}{ Sorbents } & \multicolumn{3}{|c|}{ Langmuir } & \multicolumn{3}{|c|}{ Freundlich } & \multicolumn{4}{|l|}{ D-R } \\
\hline & $\begin{array}{l}Q_{\mathrm{m}} \\
\mathrm{mg} \mathrm{g}^{-1}\end{array}$ & $\begin{array}{l}k_{\mathrm{L}} \\
\mathrm{L} \mathrm{mg}^{-1}\end{array}$ & $R^{2}$ & $n$ & $\begin{array}{l}k_{\mathrm{F}} \\
\mathrm{mg}^{1-\mathrm{n}} \mathrm{L}^{\mathrm{n}} \mathrm{g}^{-1}\end{array}$ & $R^{2}$ & $\begin{array}{l}Q_{\mathrm{m}} \\
\mathrm{mg} \mathrm{g}^{-1}\end{array}$ & $\begin{array}{l}\beta \\
\mathrm{mol}^{2}\left(\mathrm{~J}^{2}\right)^{-1}\end{array}$ & $\begin{array}{l}E \\
\mathrm{~kJ} \mathrm{~mol}^{-1}\end{array}$ & $R^{2}$ \\
\hline GC & 396.85 & 0.5796 & 0.9825 & 3.20 & 138.90 & 0.9322 & 312.85 & 0.94 & 0.73 & 0.9141 \\
\hline $\mathrm{GO} / \mathrm{Fe}_{3} \mathrm{O}_{4} / \mathrm{GC}$ & 390.70 & 0.3420 & 0.9873 & 3.49 & 118.85 & 0.9275 & 260.83 & 0.50 & 1.00 & 0.8646 \\
\hline
\end{tabular}


Table 2. Comparison of $Q_{\mathrm{m}}$ of $\mathrm{GO} / \mathrm{Fe}_{3} \mathrm{O}_{4} / \mathrm{GC}$ with reported other glucose-based sorbents for $\mathrm{U}(\mathrm{VI})$ adsorption.

\begin{tabular}{llllll}
\hline Sorbents & $\mathrm{pH}$ & Contact time & $\mathrm{m} / \mathrm{V}\left(\mathrm{g} \mathrm{L}^{-1}\right)$ & $Q_{\mathrm{m}}\left(\mathrm{mg} \mathrm{g}^{-1}\right)$ & References \\
\hline $\mathrm{HTC}$ & 6.0 & $50 \mathrm{~min}$ & 0.2 & 62.7 & {$[46]$} \\
$\mathrm{HCSs}-\mathrm{PO}_{4}-3$ & 5.0 & $30 \mathrm{~min}$ & 0.2 & 285.70 & {$[47]$} \\
$\mathrm{HTC}-\mathrm{COOH}$ & 4.5 & $22 \mathrm{~h}$ & 0.5 & 163 & {$[48]$} \\
$\mathrm{GC}$ & 6.0 & $24 \mathrm{~h}$ & 0.15 & 396.85 & This work \\
$\mathrm{GO} / \mathrm{Fe}_{3} \mathrm{O}_{4} / \mathrm{GC}$ & 5.0 & $30 \mathrm{~min}$ & 0.15 & 390.70 & This work \\
\hline
\end{tabular}

Adsorption kinetics. Figure 7 presents the time-dependent adsorption rate over contact time ranging from 5 min to 24 h of $\mathrm{U}(\mathrm{VI})$ by GC, MGC and GO/Fe $3 \mathrm{O}_{4} / \mathrm{GC}$. As shown in Fig. 7, the adsorption kinetic of $\mathrm{GO} / \mathrm{Fe}_{3} \mathrm{O}_{4} / \mathrm{GC}$ toward U(VI) indicated a fast adsorption process, and the remove of $\mathrm{U}(\mathrm{VI})$ could reach above $98 \%$ within $30 \mathrm{~min}$. But the remove of U(VI) by GC could reach $97 \%$ after $24 \mathrm{~h}$. Moreover, as presented in Fig. 7 (insert A and B), the correlation coefficients of pseudo second-order model were superior compared to pseudo first-order model which showed that the adsorption of $\mathrm{UO}_{2}{ }^{2+}$ ions onto $\mathrm{GO} / \mathrm{Fe}_{3} \mathrm{O}_{4} / \mathrm{GC}$ was well fitted by the pseudo-second-order model. Adsorption kinetic parameters of the pseudo first-order and pseudo second-order model for $\mathrm{GC}, \mathrm{MGC}$ and $\mathrm{GO} / \mathrm{Fe}_{3} \mathrm{O}_{4} / \mathrm{GC}$ were given in Table 3 . The results suggested that the interaction between $\mathrm{UO}_{2}{ }^{2+}$ and the as-prepared adsorbents is controlled by chemical sorption in the rate-controlling steps $^{49}$.

Table 3. Parameters of the pseudo first-order and second-order kinetic models for $\mathrm{U}$ adsorption on $\mathrm{GC}, \mathrm{MGC}$ and $\mathrm{GO} / \mathrm{Fe}_{3} \mathrm{O}_{4} / \mathrm{GC}$.

\begin{tabular}{lllllll}
\hline \multirow{2}{*}{ Sorbents } & \multicolumn{5}{l}{ Pseudo first-order model } & \multicolumn{5}{l}{ Pseudo second-order model } \\
\cline { 2 - 6 } & $Q_{e}\left(\mathrm{mg} \mathrm{g}^{-1}\right)$ & $k_{1}\left(\mathrm{~min}^{-1}\right)$ & $R^{2}$ & $Q_{e}\left(\mathrm{mg} \mathrm{g}^{-1}\right)$ & $k_{2}\left(\mathrm{~g}(\mathrm{mg} \cdot \mathrm{min})^{-1}\right)$ & $R^{2}$ \\
\hline $\mathrm{GC}$ & 19.3598 & 0.0930 & 0.8016 & 63.82 & 0.0547 & 0.9989 \\
$\mathrm{MGC}$ & 26.2452 & 0.0098 & 0.2288 & 44.50 & 0.4763 & 0.9999 \\
$\mathrm{GO} / \mathrm{Fe}_{3} \mathrm{O}_{4} / \mathrm{GC}$ & 0.7619 & 0.0788 & 0.3240 & 66.36 & 1.7671 & 1.0000 \\
\hline
\end{tabular}

Adsorption thermodynamics. The plots of $\ln K_{\mathrm{d}}$ versus $1 / T$ onto $\mathrm{GC}$ and $\mathrm{GO} / \mathrm{Fe}_{3} \mathrm{O}_{4} / \mathrm{GC}$ were shown in Fig. 8. The thermodynamic parameters such as enthalpy $\left(\Delta H^{0}\right)$, entropy $\left(\Delta S^{0}\right)$ and standard free energy $\left(\Delta G^{0}\right)$ from $303 \mathrm{~K}$ to $333 \mathrm{~K}$ in the adsorption processes were calculated according to Eqs. (5) and (6) and given in Table 4. The negative value of $\Delta H^{0}$ for GC reflected that the adsorption reaction was endothermic. While the positive value of $\Delta H^{0}$ for $\mathrm{GO} / \mathrm{Fe}_{3} \mathrm{O}_{4} / \mathrm{GC}$ reflected that the adsorption reaction was exothermic. The positive $\Delta S^{0}$ and negative $\Delta G^{0}$ suggested that the spontaneity of the adsorption process.

$\ln K_{d}=-\frac{\Delta H^{0}}{R T}+\frac{\Delta S^{0}}{R}$

$\Delta G^{0}=\Delta H^{0}-T \Delta S^{0}$,

Table 4. Thermodynamic parameters of $\mathrm{U}(\mathrm{VI})$ adsorption on $\mathrm{GC}$ and $\mathrm{GO} / \mathrm{Fe}_{3} \mathrm{O}_{4} / \mathrm{GC}$.

\begin{tabular}{|c|c|c|c|c|c|c|}
\hline \multirow{2}{*}{ Sorbents } & \multirow{2}{*}{$\Delta H^{0}\left(\mathrm{~kJ} \mathrm{~mol}^{-1}\right)$} & \multirow{2}{*}{$\Delta S^{0}\left(\mathrm{~J}(\mathrm{~mol} \cdot \mathrm{k})^{-1}\right)$} & \multicolumn{4}{|c|}{$\Delta G^{0}\left(\mathrm{~kJ} \mathrm{~mol}^{-1}\right)$} \\
\hline & & & $303 \mathrm{~K}$ & $313 \mathrm{~K}$ & $323 \mathrm{~K}$ & $333 \mathrm{~K}$ \\
\hline GC & -10.31 & 0.28 & -10.3948 & -10.3976 & -10.4004 & -10.4032 \\
\hline $\mathrm{GO} / \mathrm{Fe}_{3} \mathrm{O}_{4} / \mathrm{GC}$ & 11.57 & 65.42 & -8.2523 & -8.9065 & -9.5607 & -10.2149 \\
\hline
\end{tabular}

Regenerability of $\mathrm{GO} / \mathrm{Fe}_{3} \mathrm{O}_{4} / \mathrm{GC}$. Regeneration is an important aspect in the process of wastewater treatment in view of the cost saving. The reuse of $\mathrm{GO} / \mathrm{Fe}_{3} \mathrm{O}_{4} / \mathrm{GC}$ was examined in this study. After the adsorption experiments, the obtained U-loaded $\mathrm{GO} / \mathrm{Fe}_{3} \mathrm{O}_{4} / \mathrm{GC}$ was rinsed and washed with the regenerant $\left(3 \mathrm{M} \mathrm{HNO}_{3}\right)$ and the deionized water (DW) thoroughly until $\mathrm{U}(\mathrm{VI})$ ions were not detected in the rinse solution. Then, the dried and regenerated $\mathrm{GO} / \mathrm{Fe}_{3} \mathrm{O}_{4} / \mathrm{GC}$ was reused for the further adsorption experiments (the adsorption conditions: $\mathrm{pH}=5.0, C_{0}(\mathrm{U})=10 \mathrm{mg} \mathrm{L}^{-1}, T=298 \mathrm{~K}$, adsorbent dosage $=0.15 \mathrm{~g} \mathrm{~L}^{-1}$, and contact time $=24 \mathrm{~h}$ ). The results proved that $\mathrm{GO} / \mathrm{Fe}_{3} \mathrm{O}_{4} / \mathrm{GC}$ was used repeatedly for the $\mathrm{U}(\mathrm{VI})$ adsorption, and the $\mathrm{U}(\mathrm{VI})$ removal rate reached $85.45 \%$ after five cycles.

\section{Materials and methods}


Materials. Uranyl nitrate $\left(\mathrm{UO}_{2}\left(\mathrm{NO}_{3}\right)_{2} \cdot 6 \mathrm{H}_{2} \mathrm{O}\right)$ was purchased from Xi' an Dingtian Chemical Reagent Co. (China). The stock solutions of uranium $\left(5 \sim 150 \mathrm{mg} \mathrm{L}^{-1}\right)$ were prepared by dissolving $\mathrm{UO}_{2}\left(\mathrm{NO}_{3}\right)_{2} \cdot 6 \mathrm{H}_{2} \mathrm{O}$ in DW and acidified with a small amount of concentrated $\mathrm{HNO}_{3}$. Glucose was obtained from Chengdu Keshi Reagent Co. (China). All reagents were of analytical grade and used without further purification. DW was used throughout the experiments.

Synthesis of glucose-COOH (GC). The hydrothermal carbon (HTC) was synthesized using glucose via a hydrothermal method. Briefly, $6 \mathrm{~g}$ of glucose were dissolved in $60 \mathrm{~mL} \mathrm{DW}$ and placed in a Teflonlined autoclave at $453 \mathrm{~K}$ for $24 \mathrm{~h}$. After the autoclave was cooled to room temperature, the solid product HTC was filtered and washed with DW until the filtrate was colorless, and finally dried at $333 \mathrm{~K}$ under a vacuum. Finally, carboxyl-rich glucose-COOH (GC) was obtained by heating HTC in a muffle for $5 \mathrm{~h}$ at $573 \mathrm{~K}$.

Synthesis of magnetic glucose-COOH (MGC). Firstly, $0.5 \mathrm{~g}$ of GC was dissolved in $100 \mathrm{~mL} \mathrm{DW}$. Then, $30 \%$ $\mathrm{NH}_{3} \cdot \mathrm{H}_{2} \mathrm{O}$ solution was added to the $\mathrm{GC}$ solution until the solution $\mathrm{pH}$ becomes $11.1 .25 \mathrm{~g}$ of $\mathrm{FeSO}_{4} \cdot 7 \mathrm{H}_{2} \mathrm{O}$ was added slowly to the mixture under stirring. After stirring for $3 \mathrm{~h}$, the black product (MGC) was collected by magnetic separation, and completely washed with DW and ethanol. Finally, MGC was dried at $323 \mathrm{~K}$ in vacuum.

Synthesis of magnetic composite $\mathrm{GO} / \mathrm{Fe}_{3} \mathrm{O}_{4} / \mathrm{GC}$. Firstly, GO was prepared from natural graphite by the modified Hummers method ${ }^{50}$. In a typical synthesis of $\mathrm{GO} / \mathrm{Fe}_{3} \mathrm{O}_{4} / \mathrm{GC}$, the mixture of $0.25 \mathrm{~g}$ of GO and $0.25 \mathrm{~g}$ of GC was dispersed in $100 \mathrm{~mL} \mathrm{DW}$ under ultrasonic radiation for $3 \mathrm{~h}$. Then, $30 \% \mathrm{NH}_{3} \cdot \mathrm{H}_{2} \mathrm{O}$ solution was added to the $\mathrm{GO} / \mathrm{GC}$ solution until the solution $\mathrm{pH}$ becomes $11.1 .25 \mathrm{~g}$ of $\mathrm{FeSO}_{4} \cdot 7 \mathrm{H}_{2} \mathrm{O}$ was added slowly to the mixture with continuous stirring. After stirring for $3 \mathrm{~h}$, the magnetic black product $\left(\mathrm{GO} / \mathrm{Fe}_{3} \mathrm{O}_{4} / \mathrm{GC}\right)$ was collected by magnetic separation, and washed with DW and ethanol. Finally, the product was dried at $323 \mathrm{~K}$ in vacuum.

Characterization. The Fourier transform infrared (FTIR) spectra of the as-prepared adsorbents were obtained using a FTIR spectrometer (Bruker VERTEX 70, Germany). The crystal phases of the samples were characterized by X-ray diffraction (XRD) pattern (Dandong 2700 model, China). The morphologies of the products were determined using Scanning Electron Microscope (SEM) (FEI Helios 600i, USA). The magnetic measurements of $\mathrm{Fe}_{3} \mathrm{O}_{4}$ and $\mathrm{GO} / \mathrm{Fe}_{3} \mathrm{O}_{4} / \mathrm{GC}$ were conducted at $300 \mathrm{~K}$ under a varying magnetic field (PPMS-9 ECII, USA Quantum Design Co.). X-ray photoelectron spectrometer (XPS) (Thermo Fisher ESCALAB 250, USA) was used to analyze the chemical composition of the samples. Thermal stability of the products was studied by a thermogravimetric analysis (TGA) system (Netzsch STA449F3, Germany) from 30 to $900{ }^{\circ} \mathrm{C}$ at a heating rate of $10 \mathrm{~K} \mathrm{~min}^{-1}$ under an argon flow.

Adsorption experiments. The influence of $\mathrm{pH}$, co-existing cations, contact time, initial $\mathrm{U}(\mathrm{VI})$ concentration, and temperature on the $\mathrm{U}(\mathrm{VI})$ removal was investigated. The $\mathrm{U}(\mathrm{VI})$ solution $\mathrm{pH}$ was adjusted to the desired value using $\mathrm{HCl}$ and $\mathrm{NaOH}$. The as-prepared adsorbent was added to $20 \mathrm{~mL}$ solution and shaken in a shaker (Kangshi, China). After filtration, the U(VI) concentrations in solutions were determined by an MUA micro-quantity uranium analyzer (Beijing Yulun, China). The removal rate $(R, \%)$ and adsorption capacity $\left(Q, \mathrm{mg} \mathrm{g}^{-1}\right)$ were calculated according to Eqs. (7) and (8), respectively.

$R(\%)=\frac{c_{0}-c_{t}}{c_{0}} \times 100$

$Q\left(m g \cdot g^{-1}\right)=\frac{\left(c_{0}-c_{t}\right)}{W} \times V$,

where $c_{0}\left(\mathrm{mg} \mathrm{L}^{-1}\right)$ is the initial $\mathrm{U}(\mathrm{VI})$ concentration; $c_{t}\left(\mathrm{mg} \mathrm{L}^{-1}\right)$ is the $\mathrm{U}(\mathrm{VI})$ concentration at time $t$; $V$ is the volume of the solution $(\mathrm{L}) ; W$ is the dosage of the adsorbent $(\mathrm{g})$.

\section{Conclusions}

In summary, three adsorbents $\mathrm{GC}, \mathrm{MGC}$ and $\mathrm{GO} / \mathrm{Fe}_{3} \mathrm{O}_{4} / \mathrm{GC}$ were facilely prepared using the inexpensive and environmentally benign glucose as a raw material for $\mathrm{U}(\mathrm{VI})$ capture via the simple hydrothermal carbonization and magnetization reaction. The optimum adsorption conditions for $\mathrm{U}(\mathrm{VI})$ with the initial concentration of $10 \mathrm{mg} \mathrm{L}^{-1}$ was at a $\mathrm{pH}$ of 5.0, a dosage of $0.15 \mathrm{~g} \mathrm{~L}^{-1}$, and contact time of within $30 \mathrm{~min}$ when using $\mathrm{GO} / \mathrm{Fe}_{3} \mathrm{O}_{4} / \mathrm{GC}$ as the adsorbent. The existence of co-existing ions in solutions such as $\mathrm{Na}^{+}, \mathrm{K}^{+}, \mathrm{Mg}^{2+}, \mathrm{Ca}^{2+}$ and $\mathrm{Al}^{3+}$ had different influence on the removal of uranium by $\mathrm{GO} / \mathrm{Fe}_{3} \mathrm{O}_{4} / \mathrm{GC}$. Adsorption data of $\mathrm{U}(\mathrm{VI})$ by $\mathrm{GO} / \mathrm{Fe}_{3} \mathrm{O}_{4} / \mathrm{GC}$ were in good agreement with Langmuir isotherm 
model and pseudo-second-order kinetic model. The composite $\mathrm{GO} / \mathrm{Fe}_{3} \mathrm{O}_{4} / \mathrm{GC}$ exhibited excellent $\mathrm{U}(\mathrm{VI})$ sorption capacities (390.70 mg g $\mathrm{g}^{-1}$ ), and a faster adsorption rate than those of GC, MGC and the previously reported glucose-based materials.

The superior $\mathrm{U}(\mathrm{VI})$ uptake and fast solid-liquid separation after adsorption were mainly attributed to the abundant presence of $\mathrm{GO}$ and magnetic $\mathrm{Fe}_{3} \mathrm{O}_{4}$ particles in the molecule of $\mathrm{GO} / \mathrm{Fe}_{3} \mathrm{O}_{4} / \mathrm{GC}$. The facile production and high stability of $\mathrm{GO} / \mathrm{Fe}_{3} \mathrm{O}_{4} / \mathrm{GC}$ reinforce its potential in the industrial purification of various pollutants, which paves the way for a new route to develop a novel glucose-based composite as a low-cost and highly efficient adsorbent to remove U(VI) from uranium-containing waste influents. The as-prepared $\mathrm{GO} / \mathrm{Fe}_{3} \mathrm{O}_{4} / \mathrm{GC}$ has good regenerability which is very important in the practical application.

\section{References}

1. Ma, F., Ding, S. L., Ren, H. J. \& Liu, Y. H. Sakura-based activated carbon preparation and its performance in supercapacitor applications. RSC Adv. 9, 2474-2483 (2019).

2. Bulusheva, L. G., Sysoev, V. I., Lobiak, E. V., Fedoseeva, Y. V., Makarova, A. A., Dubois, M., Flahaut, E. \& Okotrub, A. V. Chlorinated holey double-walled carbon nanotubes for relative humidity sensors. Carbon 148, 413-420 (2019).

3. Xin, B. W. et al. Carbon fiber-promoted activation of catalyst for efficient growth of single-walled carbon nanotubes. Carbon 156, 410-415 (2020).

4. Kwon, H. N., Park, G. D., Kang, Y. C. \& Roh, K. C. Fabrication of bimodal micro-mesoporous amorphous carbongraphitic carbon-reduced graphene oxide composite microspheres prepared by pilot-scale spray drying and their application in supercapacitors. Carbon 144, 591-600 (2019).

5. Kim, Y. J., Hong, I., Shim, J. \& An. J. C. Preparation and characterization of black liquor-derived activated carbon by self chemical activation. Carbon Lett. 30, 115-121(2020).

6. Pi, L. et al. Bionic preparation of $\mathrm{CeO}_{2}$ encapsulated nitrogen self-doped biochars for highly efficient oxygen reduction. ACS Appl. Mater. Interfaces 12, 3642-3653 (2020).

7. Liu, W. J., Li, W. W., Jiang, H. \& Yu, H. Q. Fates of chemical elements in biomass during its pyrolysis. Chem. Rev. 117, 6367-6398 (2017).

8. Mitina, A. A, Redkin, A. N. \& Yakimov, E. E. New way of the nickel catalyst preparation for carbon nanotubes synthesis by pyrolysis of ethanol vapor. Fuller. Nanotub. Car. N. 28(2), 112-117 (2020).

9. Wang, J. L. \& Wang, S. Z. Preparation, modification and environmental application of biochar: A review. J. Clean. Prod. 227, 1002-1022 (2019).

10. Aftab, F. et al. A facile synthesis of FeCo nanoparticles encapsulated in hierarchical N-Doped carbon nanotube/nanofiber hybrids for overall water splitting. ChemCatChem. 12, 932-943 (2020).

11. Tooming, T., Thomberg, T., Kurig, H., Jänes, A. \& Lust, E. High power density supercapacitors based on the carbon dioxide activated D-glucose derived carbon electrodes and 1-ethyl-3-methylimidazolium tetrafluoroborate ionic liquid.

J. Power Sources 280, 667-677 (2015).

12. Liu, Z. et al. New strategy to prepare ultramicroporous carbon by ionic activation for superior $\mathrm{CO}_{2}$ capture. Chem. Eng. J. 337, 290-299 (2018).

13. Wang, Y. M., Zhou, Y. L., Jiang, G. J., Chen, P. R. \& Chen, Z. One-step fabrication of carbonaceous adsorbent from corncob for enhancing adsorption capability of methylene blue removal. Sci. Rep. 10, 12515 (2020).

14. Cai, H. M., Lin, X. Y., Tian, L. Y. \& Luo, X. G. One-step hydrothermal synthesis of carbonaceous spheres from glucose with an aluminum chloride catalyst and its adsorption characteristic for uranium(VI). Ind. Eng. Chem. Res. 55, 9648-9656 (2016).

15. Luo, X. W. et al. Hydrothermal carbonization of sewage sludge and in-situ preparation of hydrochar/MgAl-layered double hydroxides composites for adsorption of Pb(II). J. Clean. Prod. 258, 120991 (2020).

16. Chen, W. H., Zhang, G. C., Li, D., Ma, S. G., Wang, B. D. \& Jiang, X. Preparation of nitrogen-doped porous carbon from waste polyurethane foam by hydrothermal carbonization for $\mathrm{H}_{2} \mathrm{~S}$ adsorption. Ind. Eng. Chem. Res. 59, 7447-7456 (2020).

17. Wu, J., Yang, J., Huang, G., Xu, C. \& Lin, B. Hydrothermal carbonization synthesis of cassava slag biochar with excellent adsorption performance for Rhodamine B. J. Clean. Prod. 251, https://doi.org/10.1016/j.jclepro.2019.119717 
(2020).

18. Yang, G. Z., Song, S., Li, J., Tang, Z. H., Ye, J. Y. \& Yang, J. H. Preparation and $\mathrm{CO}_{2}$ adsorption properties of porous carbon by hydrothermal carbonization of tree leaves. J. Mater. Sci. Technol. 35, 875-884 (2019).

19. Sheng, K. C. et al. Hydrothermal carbonization of cellulose and xylan into hydrochars and application on glucose isomerization. J. Clean. Prod. 237, 117831 (2019).

20. Schonvogel, D. et al. Hydrothermal carbonization-derived carbon from waste biomass as renewable Pt support for fuel cell applications: role of carbon activation. Energy Technol, 7, 1900344 (2019).

21. Ning, X. J. et al. Physiochemical, structural and combustion properties of hydrochar obtained by hydrothermal carbonization of waste polyvinyl chloride. Fuel 270, 117526 (2020).

22. Sharma, H. B., Sarmah, A. K. \& Dubey, B. Hydrothermal carbonization of renewable waste biomass for solid biofuel production: A discussion on process mechanism, the influence of process parameters, environmental performance and fuel properties of hydrochar. Renew. Sust. Energ. Rev. 123, 109761 (2020).

23. Shi, N. et al. Formation of soluble furanic and carbocyclic oxy-organics during the hydrothermal carbonization of glucose. Energy Fuels 34, 1830-1840 (2020).

24. Elaigwu, S. E. \& Greenway, G. M. Chemical, structural and energy properties of hydrochars from microwave-assisted hydrothermal carbonization of glucose. Int. J. Ind. Chem. 7, 449-456 (2016).

25. Yang, Z. et al. Facile synthesis of high-performance nitrogen-doped hierarchically porous carbon for catalytic oxidation. ACS Sustainable Chem. Eng. 8, 4236-4243 (2020).

26. Jaramillo, D. E. et al. Selective nitrogen adsorption via backbonding in a metal-organic framework with exposed vanadium sites. Nature Mater. 19, 517-521 (2020).

27. Gupta, K. M., Zhang, K. \& Jiang, J. W. Glucose recovery from aqueous solutions by adsorption in metal-organic framework MIL-101: a molecular simulation study. Sci. Rep. 5, 12821 (2015).

28. Wang, B., Xu, X. Y., Tang, H., Mao, Y. L., Chen, H. H. \& Ji, FY. Highly efficient adsorption of three antibiotics from aqueous solutions using glucose-based mesoporous carbon. Appl. Surf. Sci. 528, 147048 (2020).

29. Li, K. R., Zhou, M. H., Liang, L., Jiang, L. L. \& Wang, W. Ultrahigh-surface-area activated carbon aerogels derived from glucose for high-performance organic pollutants adsorption. J. Colloid Interf. Sci. 546, 333-343 (2019).

30. Yue, L. M. et al. Efficient $\mathrm{CO}_{2}$ adsorption on nitrogen-doped porous carbons derived from D glucose. Energy Fuels 32 , 6955-6963 (2018).

31. Meng, L. et al. Surface carboxyl-activated polyester (PET) fibers decorated with glucose carbon microspheres and their enhanced selective adsorption for dyes. J. Phys. Chem. Solids 123(1), 378-388 (2018).

32. Cai, H. M., Lin, X. Y., Qin, Y. \& Luo, X. G. Hydrothermal synthesis of carbon microsphere from glucose at low temperature and its adsorption property of uranium(VI). J. Radioanal. Nucl. Chem. 311, 695-706 (2017).

33. Wang, G. F., Wang, S., Sun, W., Sun, Z. M. \& Zheng, S. L. Synthesis of a novel illite@carbon nanocomposite adsorbent for removal of Cr(VI) from wastewater. J. Environ. Sci. 57, 62-71 (2017).

34. Jiang, X. Q., Ruan, G. H., Huang, Y. P., Chen, Z. Y., Yuan, H. M. \& Du, F. Y. Assembly and application advancement of organic-functionalized graphene-based materials: A review. J. Sep. Sci. 43, 1544-1557 (2020).

35. Ahmad, S. Z. N., Salleh, W. N. W., Ismail, A. F., Yusof, N., Yusop, M. Z. M. \& Aziz, F. Adsorptive removal of heavy metal ions using graphene-based nanomaterials: Toxicity, roles of functional groups and mechanisms. Chemosphere 248, 126008 (2020).

36. Smith, A. T., Marie, A., Zeng, S., Liu, B. \& Sun, L. Synthesis, properties, and applications of graphene oxide/reduced graphene oxide and their nanocomposites. Nano Mater. Sci. 1, 31-47 (2019).

37. Xie, A. T. et al. Novel graphene oxide-confined nanospace directed synthesis of glucose-based porous carbon nanosheets with enhanced adsorption performance. ACS Sustainable Chem. Eng. 5, 11566-11576 (2017).

38. Martín-Jimeno, F. J., Suárez-García, F., Paredes, J. I., Martínez-Alonso, A. \& Tascón, J. M. D. Activated carbon xerogels with a cellular morphology derived from hydrothermally carbonized glucose-graphene oxide hybrids and their performance towards $\mathrm{CO}_{2}$ and dye adsorption. Carbon 81, 137-147 (2015).

39. $\mathrm{Yu}$, J. et al. Hollow $\mathrm{FeP} / \mathrm{Fe}_{3} \mathrm{O}_{4}$ hybrid nanoparticles on carbon nanotubes as efficient electrocatalysts for the oxygen evolution reaction. ACS Appl. Mater. Interfaces 12, 12783-12792 (2020).

40. Pan, J. L. et al. Shape anisotropic $\mathrm{Fe}_{3} \mathrm{O}_{4}$ nanotubes for efficient microwave absorption. Nano Res. 13(3), 621-629 
(2020).

41. Boruah, P. K., Borah, D. J., Handique, J., Sharma, P., Sengupta, P. \& Das, M. R. Facile synthesis and characterization of $\mathrm{Fe}_{3} \mathrm{O}_{4}$ nanopowder and $\mathrm{Fe}_{3} \mathrm{O}_{4} /$ reduced graphene oxide nanocomposite for methyl blue adsorption: A comparative study. J. Environ.Chem. Eng. 3(3), 1974-1985 (2015).

42. Cai, H. M., Lin, X. Y., Qin, Y. \& Luo, X. G. Hydrothermal synthesis of carbon microsphere from glucose at low temperature and its adsorption property of uranium(VI). J. Radioanal. Nucl. Chem. 311, 695-706 (2017).

43. Liu, T. \& Xu, Y. B. Synthesis of nanocrystalline $\mathrm{LaFeO}_{3}$ powders via glucose sol-gel route. Mater. Chem. Phys. 129, 1047-1050 (2011).

44. Liu, X. H. et al. Polyaniline (PANI) modified bentonite by plasma technique for U(VI) removal from aqueous solution. Appl. Surf. Sci. 411, 331-337 (2017).

45. Liu, R., Zhang, W., Chen, Y. T. \& Wang, Y. S. Uranium (VI) adsorption by copper and copper/iron bimetallic central MOFs. Colloid. Surface. A. 587, DOI: 10.1016/j.colsurfa.2019.124334 (2020).

46. Zhang, Z. B., Cao, X. H., Liang, P. \& Liu. Y. H. Adsorption of uranium from aqueous solution using biochar produced by hydrothermal carbonization. J. Radioanal. Nucl. Chem. 295, 1201-1208 (2013).

47. Zhang, Z. B., Zho, Z. W., Cao, X. H., Liu, Y. H., Xiong, G. X. \& Liang, P. Removal of uranium(VI) from aqueous solutions by new phosphorus-containing carbon spheres synthesized via one-step hydrothermal carbonization of glucose in the presence of phosphoric acid. J. Radioanal. Nucl. Chem. 299, 1479-1487 (2014).

48. Cai, H. M., Lin, X. Y., Qin, Y. \& Luo, X. G. Hydrothermal synthesis of carbon microsphere from glucose at low temperature and its adsorption property of uranium(VI). J. Radioanal. Nucl. Chem.311, 695-706 (2017).

49. Vu, H. C., Dwivedi, A. D., Le, T. T. Seo, S. H., Kim, E. J. \& Chang, Y. S. Magnetite graphene oxide encapsulated in alginate beads for enhanced adsorption of $\mathrm{Cr}(\mathrm{VI})$ and $\mathrm{As}(\mathrm{V})$ from aqueous solutions: Role of crosslinking metal cations in pH control. Chem. Eng. J. 307(Complete), 220-229 (2017).

50. Ma, J., Liu, C. H., Li, R. \& Wang, J. Properties and structural characterization of oxide starch/chitosan/graphene oxide biodegradable nanocomposites. J. Appl. Polym. Sci. 123(5), 2933-2944 (2012).

\section{Acknowledgements}

This work is financially supported by the National Natural Science Foundation of China (21407132). We also gratefully acknowledge Jingrong Zhong, Qifa Pan, Yi Liu, Ce Ma and Bingqing Li for the characterizations of the samples.

\section{Author contributions}

Aili Yang designed and performed all the experiments, analyzed the results, and wrote the manuscript. Zhijun Wang and Yukuan Zhu carried out the adsorption experiments.

\section{Competing interests}

The authors declare no competing interests.

\section{Figure caption list}

Figure 1. The fabrication process and magnetization curve of $\mathrm{GO} / \mathrm{Fe}_{3} \mathrm{O}_{4} / \mathrm{GC}$.

Figure 2. IR spectra (A), XRD patterns (B) and TGA curves (C) of the samples.

Figure 3. XPS survey spectra of $\mathrm{Fe}_{3} \mathrm{O}_{4}$, glucose, $\mathrm{GC}, \mathrm{MGC}$ and $\mathrm{GO} / \mathrm{Fe}_{3} \mathrm{O}_{4} / \mathrm{GC}(\mathrm{A})$ and the high-resolution $\mathrm{Fe} 2 \mathrm{p}$ spectra of $\mathrm{Fe}_{3} \mathrm{O}_{4}$ and $\mathrm{GO} / \mathrm{Fe}_{3} \mathrm{O}_{4} / \mathrm{GC}(\mathrm{B})$.

Figure 4. Schematic diagram of a possible formation mechanism of $\mathrm{GO} / \mathrm{Fe}_{3} \underline{\mathrm{O}}_{4} / \mathrm{GC}$.

Figure 5. Effect of $\mathrm{pH}(\mathrm{A})$ and co-existing ions (B) on the $\mathrm{U}(\mathrm{VI})$ adsorption. $C_{(\mathrm{U}) \text { initial }}=10 \mathrm{mg} \mathrm{L}^{-1}, C_{\text {sorbent }}=0.25 \mathrm{~g} \mathrm{~L}^{-1}$, $C_{\text {co-existing ions }}=2.5 \mathrm{~g} \mathrm{~L}^{-1}$, and contact time $=30 \mathrm{~min}$.

Figure 6. The fit results of Langmuir and Freundlich (A) and D-R (B) isotherm models for $\mathrm{GC}$ and $\mathrm{GO} / \mathrm{Fe}_{3} \mathrm{O}_{4} / \mathrm{GC}$. $\mathrm{pH}=$ 
5.0 and 6.0, $C_{\text {(U)initial }}=5 \sim 150 \mathrm{mg} \mathrm{L}^{-1}, C_{\text {sorbent }}=0.15 \mathrm{~g} \mathrm{~L}^{-1}$, and contact time $=24 \mathrm{~h}$.

Figure 7. Influence of contact time on $\mathrm{U}(\mathrm{VI})$ sorption by $\mathrm{GC}, \mathrm{MGC}$ and $\mathrm{GO} / \mathrm{Fe}_{3} \mathrm{O}_{4} / \mathrm{GC}$. Insert $\mathrm{A}$ and $\mathrm{B}$ are linear fit of the pseudo first-order and pseudo second-order kinetics models, respectively. $\mathrm{pH}=5.0$ and $6.0, C_{(\mathrm{U}) \text { initial }}=10 \mathrm{mg} \mathrm{L}^{-1}$, and $C_{\text {adsorbent }}=0.15 \mathrm{~g} \mathrm{~L}^{-1}$.

Figure 8. Plots of $\ln K_{d}$ versus $1 / T$ for $\mathrm{U}(\mathrm{VI})$ adsorption onto $\mathrm{GC}$ and $\mathrm{GO} / \mathrm{Fe}_{3} \mathrm{O}_{4} / \mathrm{GC} . \mathrm{pH}=5.0$ and $6.0, C_{\text {(U)initial }}=10 \mathrm{mg}$ $\mathrm{L}^{-1}, C_{\text {sorbent }}=0.15 \mathrm{~g} \mathrm{~L}^{-1}, T=303 \mathrm{~K}, 313 \mathrm{~K}, 323 \mathrm{~K}$ and $333 \mathrm{~K}$, and contact time $=24 \mathrm{~h}$. 


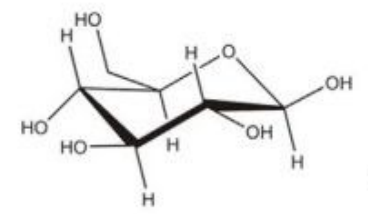

glucose

$453 \mathrm{~K}, 24 \mathrm{~h}$

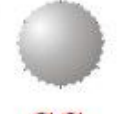

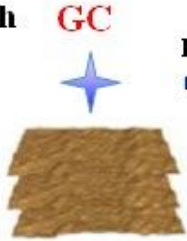

GO

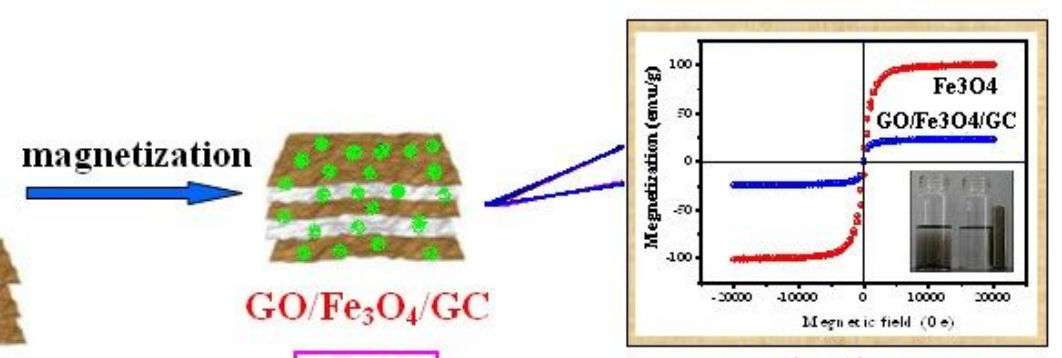

magnetization curve

Figure 1

The fabrication process and magnetization curve of GO/Fe304/GC
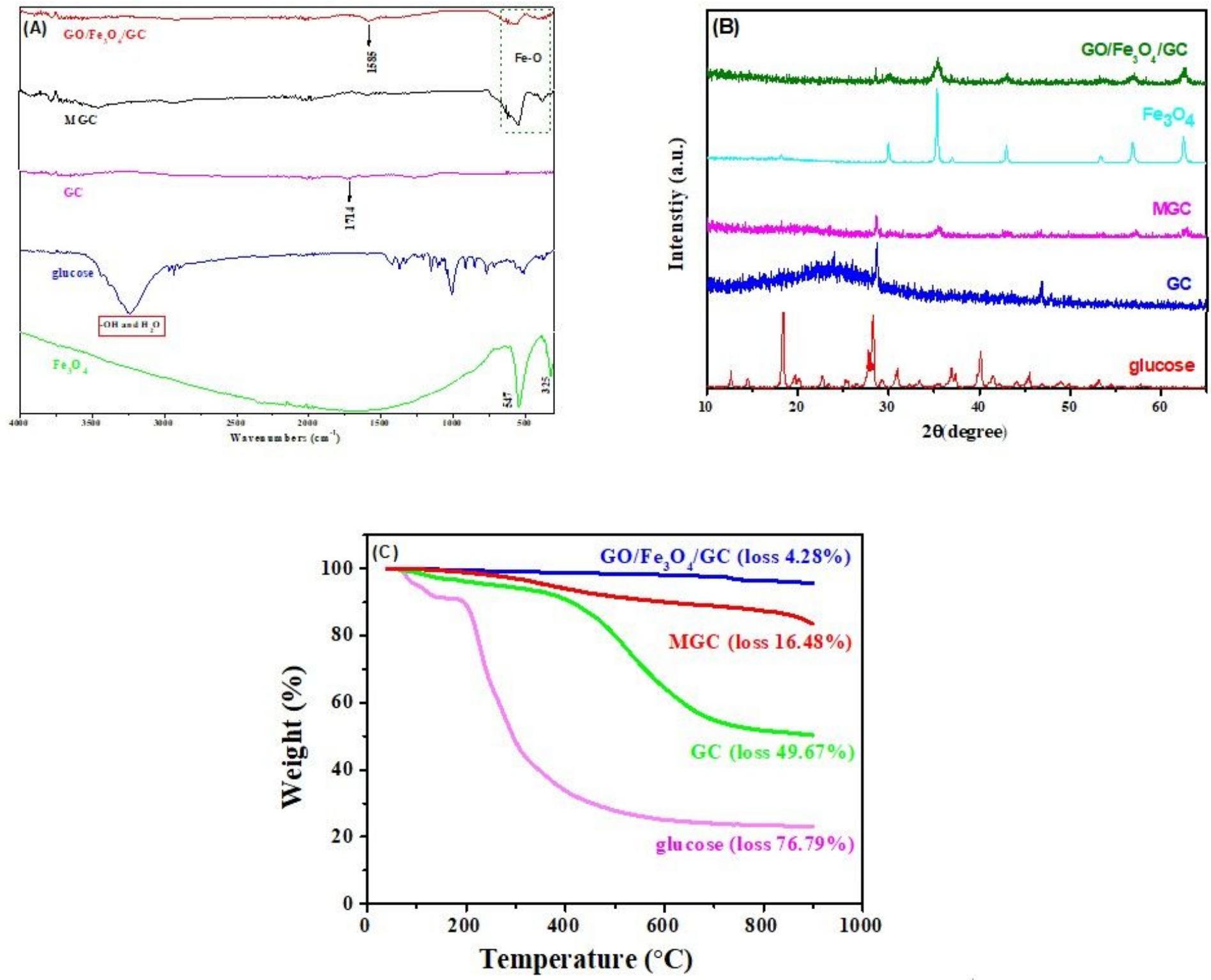
Figure 2

IR spectra (A), XRD patterns (B) and TGA curves (C) of the samples.
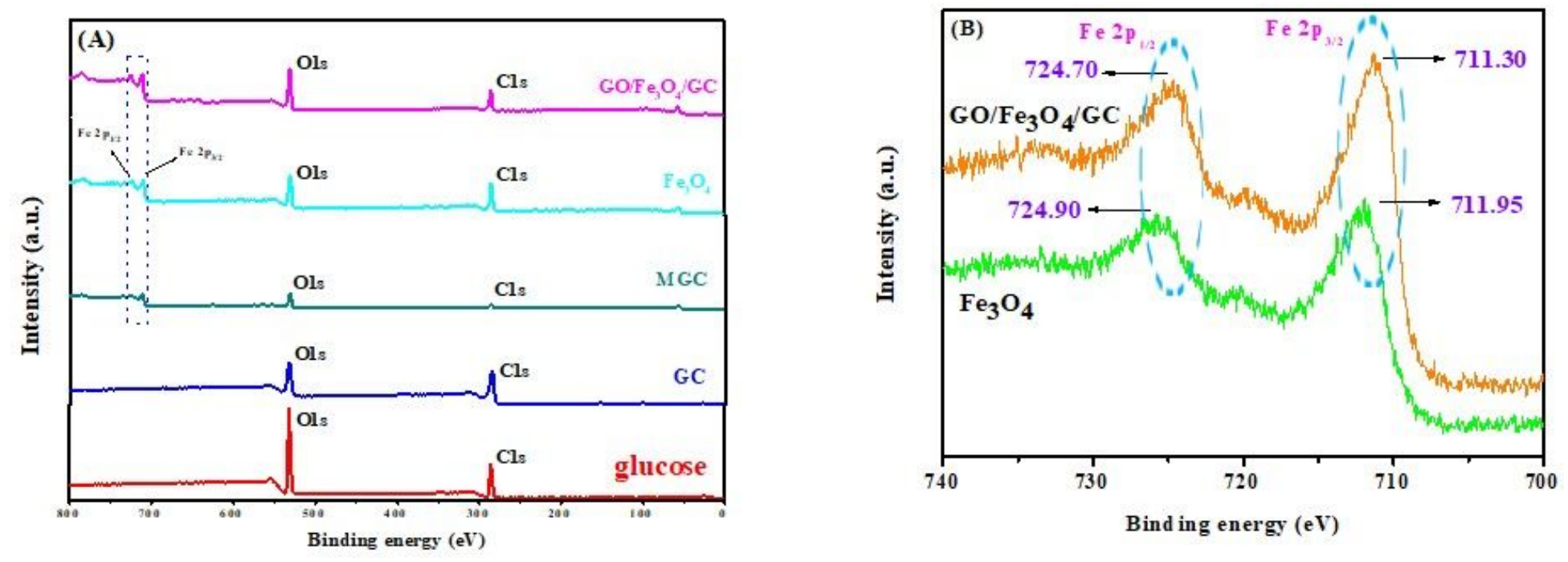

Figure 3

XPS survey spectra of Fe304, glucose, GC, MGC and GO/Fe304/GC (A) and the high-resolution Fe 2p spectra of $\mathrm{Fe} 304$ and GO/Fe304/GC (B).

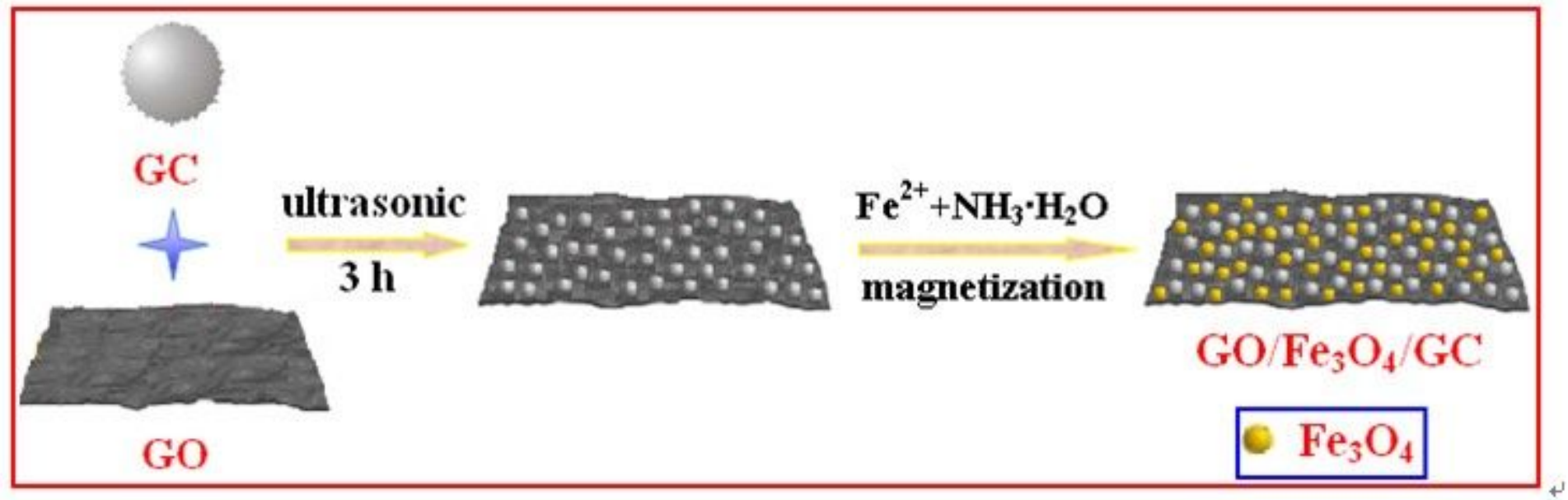

Figure 4

Schematic diagram of a possible formation mechanism of GO/Fe304/GC. 

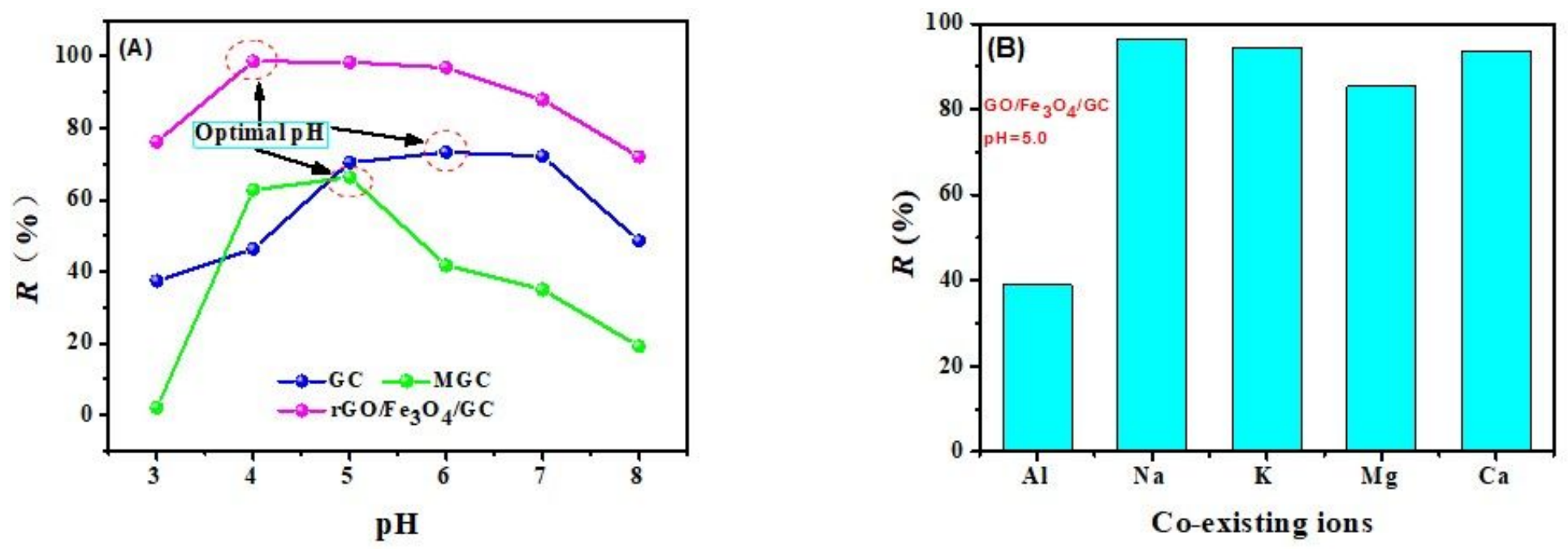

Figure 5

Effect of $\mathrm{pH}(\mathrm{A})$ and co-existing ions $(\mathrm{B})$ on the $\mathrm{U}(\mathrm{VI})$ adsorption. $\mathrm{C}(\mathrm{U})$ initial $=10 \mathrm{mg} \mathrm{L}-1, \mathrm{Csorbent}=0.25$ $\mathrm{g} \mathrm{L}-1$, Cco-existing ions $=2.5 \mathrm{~g} \mathrm{~L}-1$, and contact time $=30 \mathrm{~min}$.
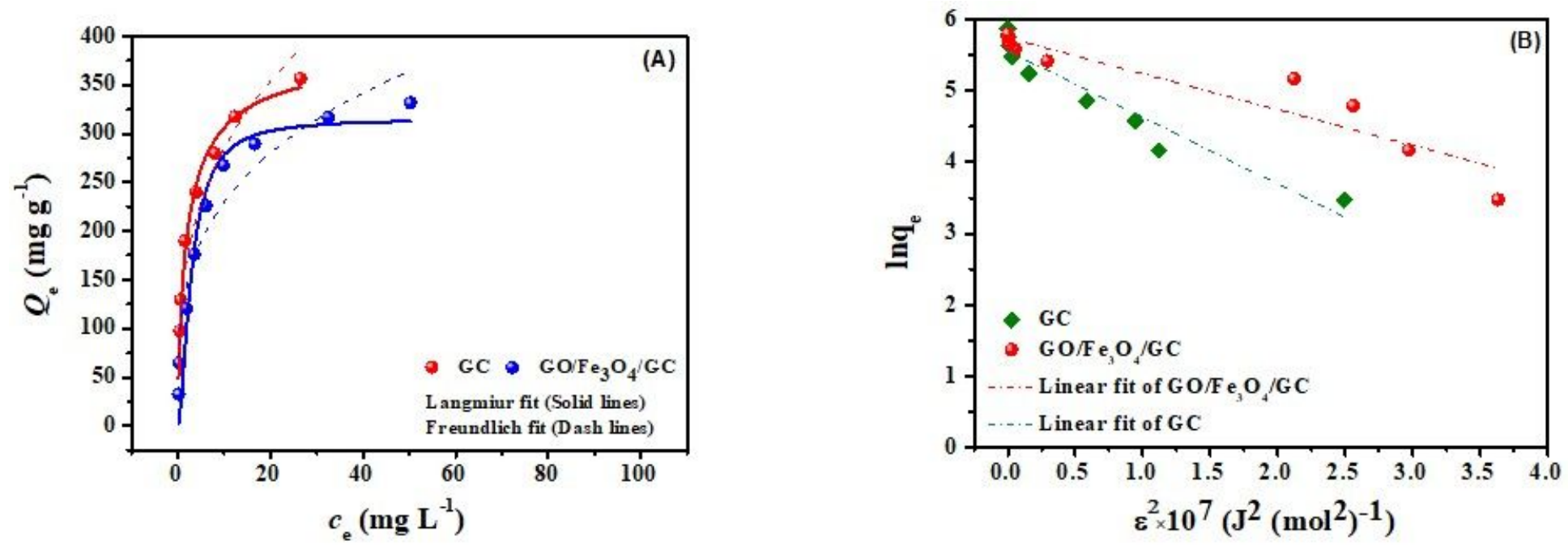

\section{Figure 6}

The fit results of Langmuir and Freundlich (A) and D-R (B) isotherm models for GC and GO/Fe304/GC. $\mathrm{pH}=5.0$ and 6.0, $\mathrm{C}(\mathrm{U})$ initial $=5 \sim 150 \mathrm{mg} \mathrm{L}-1$, Csorbent $=0.15 \mathrm{~g} \mathrm{~L}-1$, and contact time $=24 \mathrm{~h}$. 


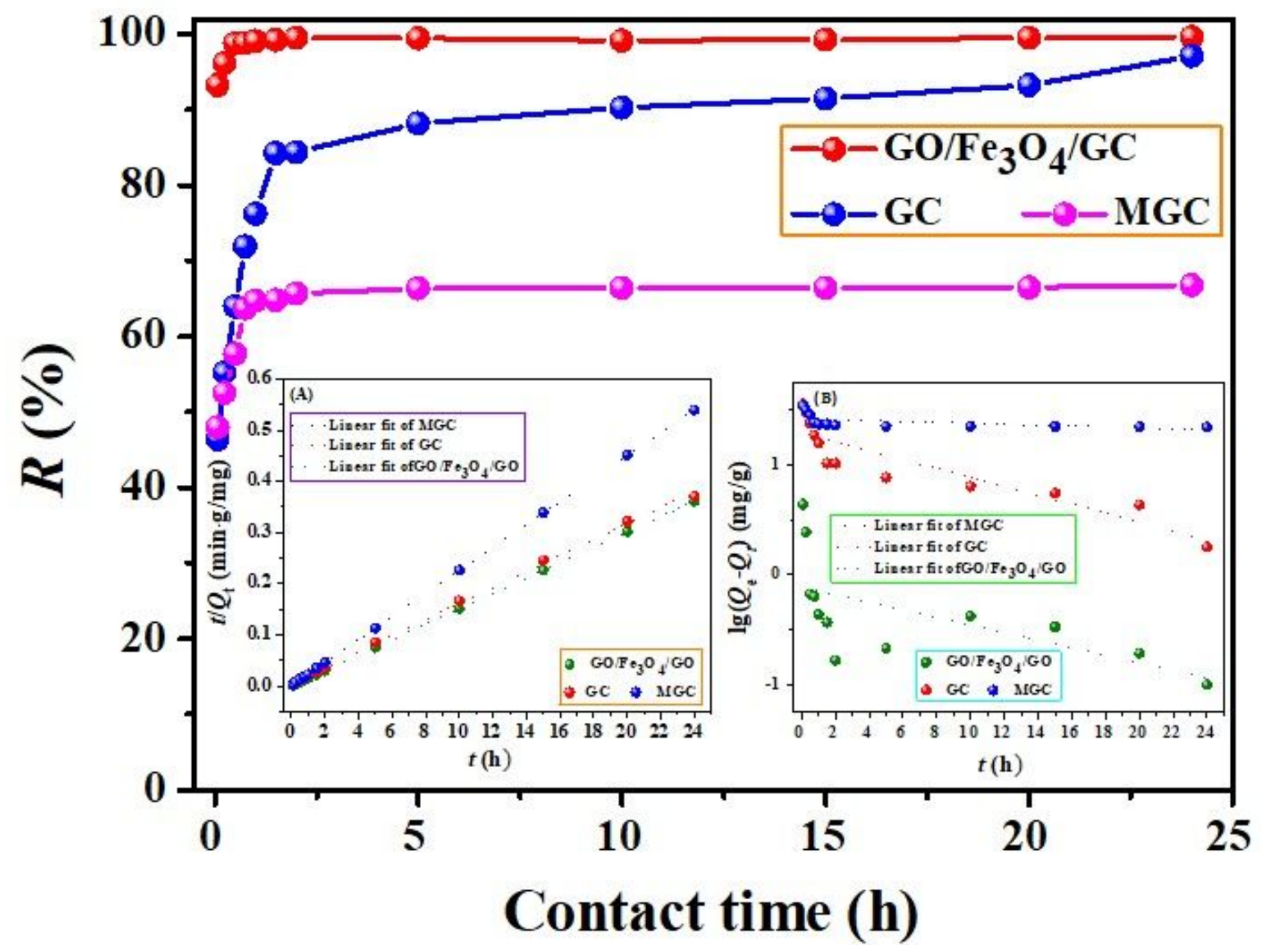

Figure 7

Influence of contact time on $\mathrm{U}(\mathrm{VI})$ sorption by GC, MGC and GO/Fe304/GC. Insert A and B are linear fit of the pseudo first-order and pseudo second-order kinetics models, respectively. $\mathrm{pH}=5.0$ and $6.0, \mathrm{C}(\mathrm{U})$ initial $=10 \mathrm{mg} \mathrm{L}-1$, and Cadsorbent $=0.15 \mathrm{~g} \mathrm{~L}-1$. 


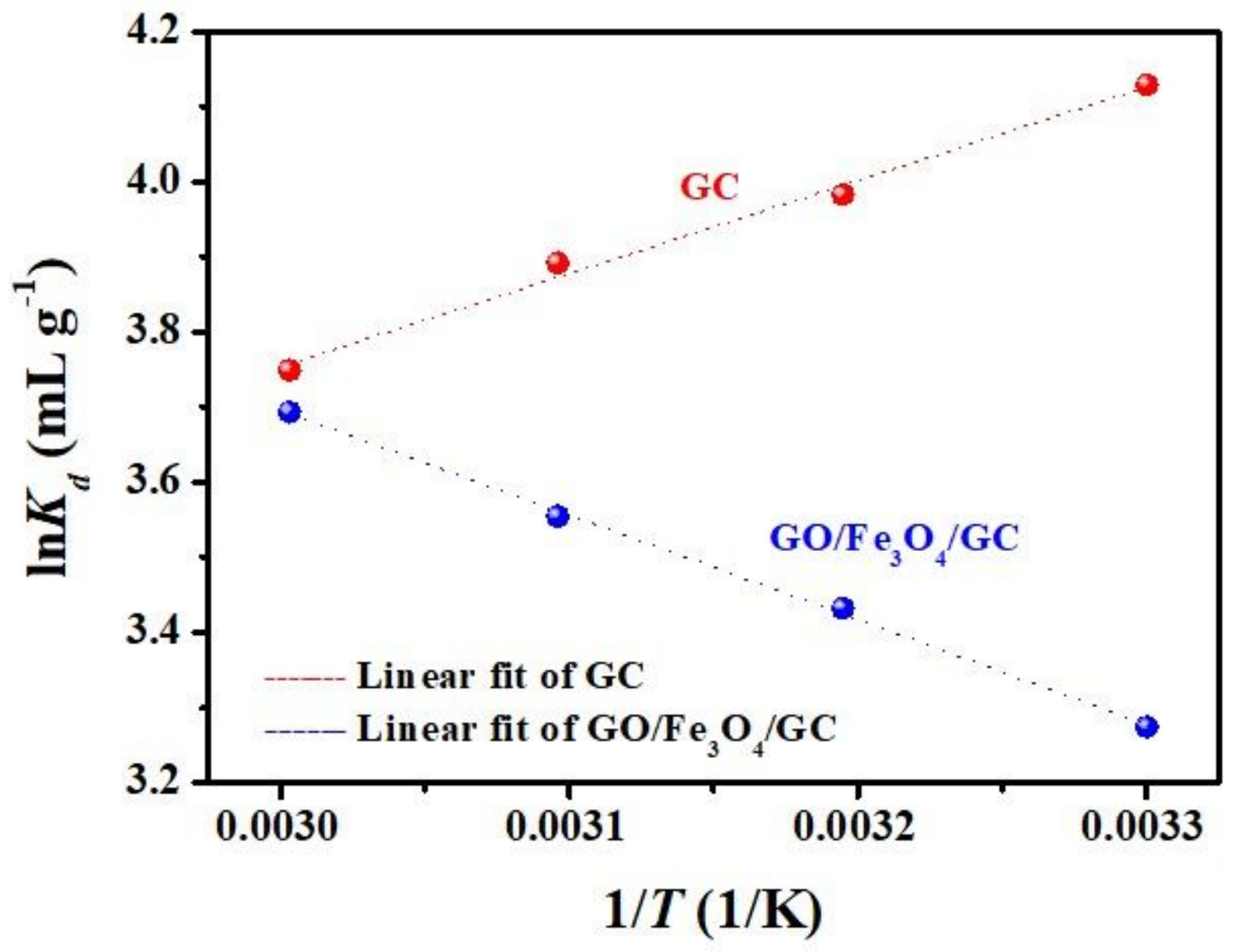

Figure 8

Plots of InKd versus 1/T for $\mathrm{U}(\mathrm{VI})$ adsorption onto $\mathrm{GC}$ and GO/Fe304/GC. $\mathrm{pH}=5.0$ and 6.0, $\mathrm{C}(\mathrm{U})$ initial $=$ $10 \mathrm{mg} \mathrm{L}-1$, Csorbent $=0.15 \mathrm{~g} \mathrm{~L}-1, \mathrm{~T}=303 \mathrm{~K}, 313 \mathrm{~K}, 323 \mathrm{~K}$ and $333 \mathrm{~K}$, and contact time $=24 \mathrm{~h}$. 